\title{
Overexpression of a Redox-Regulated Cutinase Gene, MfCUT1, Increases Virulence of the Brown Rot Pathogen Monilinia fructicola on Prunus spp.
}

\author{
Miin-Huey Lee, ${ }^{1,2}$ Chiu-Min Chiu, ${ }^{2}$ Tatiana Roubtsova, ${ }^{1}$ Chien-Ming Chou, ${ }^{2}$ and Richard M. Bostock ${ }^{1}$ \\ ${ }^{1}$ Department of Plant Pathology, University of California, One Shields Ave., Davis 95616, U.S.A.; ${ }^{2}$ Department of Plant \\ Pathology, National Chung-Hsing University, No. 250 Kao-Kuang Rd., Taichung 402, Taiwan
}

Submitted 31 May 2009. Accepted 24 September 2009.

\begin{abstract}
A 4.5-kb genomic DNA containing a Monilinia fructicola cutinase gene, MfCUT1, and its flanking regions were isolated and characterized. Sequence analysis revealed that the genomic MfCUT1 carries a 63-bp intron and a promoter region with several transcription factor binding sites that may confer redox regulation of $M f C U T 1$ expression. Redox regulation is indicated by the effect of antioxidants, shown previously to inhibit $M F C U T 1$ gene expression in cutin-induced cultures, and in the present study, where $\mathrm{H}_{2} \mathrm{O}_{2}$ enhanced $M f C U T 1$ gene expression. A $\beta$-glucuronidase (GUS) reporter gene (gusA) was fused to MfCUT1 under the control of the MfCUT1 promoter, and this construct was then used to generate an MfCUT1-GUS strain by Agrobacterium spp.-mediated transformation. The appearance of GUS activity in response to cutin and suppression of GUS activity by glucose in cutinase-inducing medium verified that the MfCUT1-GUS fusion protein was expressed correctly under the control of the MfCUT1 promoter. MfCUT1-GUS expression was detected following inoculation of peach and apple fruit, peach flower petals, and onion epidermis, and during brown rot symptom development on nectarine fruit at a relatively late stage of infection ( $24 \mathrm{~h}$ postinoculation). However, semiquantitative reverse-transcriptase polymerase chain reaction provided sensitive detection of MfCUT1 expression within $5 \mathrm{~h}$ of inoculation in both almond and peach petals. MfCUT1GUS transformants expressed $M f C U T 1$ transcripts at twice the level as the wild type and caused more severe symptoms on Prunus flower petals, consistent with MfCUT1 contributing to the virulence of $M$. fructicola.
\end{abstract}

Monilinia fructicola (G. Winter) Honey is a principal causal agent of brown rot blossom blight and fruit rot of Prunus spp. (stone fruit) and is one of the most economically damaging pathogens of this group in pre- and post-harvest settings (Ogawa et al. 1995). As part of a concerted effort to develop peach cultivars with improved brown rot resistance (Gradziel et al. 1998), we are seeking to better understand the infection biology of $M$. fructicola, for which there have been relatively few mechanistic studies. On flower petals, the pathogen predominantly infects directly through the cuticle (Lee and Bostock

Corresponding author: R. M. Bostock; Telephone: +1.530.752.0308; Fax: +1.530.752.5674; E-mail: rmbostock@ucdavis.edu

* The $e$-Xtra logo stands for "electronic extra" and indicates that six supplementary figures and two supplementary tables are published online. 2006b) whereas, on fruit, infection occurs either directly through the cuticle or indirectly through surface wounds and natural openings (Baker and Bateman 1978; Cruickshank and Wade 1992). In peach (Prunus persica (L.) Batsch), cuticle structure is related to fruit resistance to brown rot (Gradziel et al. 1998). For example, certain clingstone peach genotypes such as the South American cv. Bolinha display a high level of brown rot resistance (Feliciano et al. 1987). Bolinha fruit have a thicker cuticle and a higher concentration of surface phenols, particularly chlorogenic acid, than fruit of similar maturity from less resistant genotypes (Lee and Bostock 2007). Chlorogenic acid and, to a lesser extent, caffeic acid are present in peach peel and flesh tissue (Senter and Callahan 1990; Van Gorsel 1993; Tomas-Barberan et al. 2001; Andreotti et al. 2008). These phenols and other antioxidants inhibit cutinase gene expression in M. fructicola (Bostock et al. 1999; Wang et al. 2002).

Fungal pathogens can produce more than one cutinase (Li et al. 2002), and different cutinases within a species likely serve different functions during saprophytic or parasitic growth. $M$. fructicola produces at least four cutinase isozymes when grown on cutin as a carbon source (Wang et al. 2000). Among these, MfCUT1 is the dominant isozyme, which was purified, and its cDNA cloned and characterized (Wang et al. 2000, 2002). Classical approaches, such as inactivation with esterase inhibitors or antibodies (Dickman et al. 1983; Tanabe et al. 1988; Pascholati et al. 1993; Davies et al. 2000), and genetic methods, such as gene disruption and reporter assays, have provided rigorous assessment of cutinase function in various plant-microbe interactions (Stahl and Schafer 1992; Sweigard et al. 1992; Crowhurst et al. 1997; van Kan et al. 1997). Fungal cutinases have been shown to be important pathogenicity or virulence factors in some interactions (Dickman and Patil 1986; Pascholati et al. 1993; Rogers et al. 1994; Davies et al. 2000). However, a critical role for cutinase during pathogenesis in other cases was not supported (Bonnen and Hammerschmidt 1989; Crowhurst et al. 1997). In the genome sequence of the rice blast pathogen Magnaporthe grisea, there are 17 putative cutinases (Dean et al. 2005; Skamnioti et al. 2008). An earlier study could not show an essential role of cutinase during $M$. grisea infection of rice (Sweigard et al. 1992). However, a more recent study focusing on one of the cutinase family members, CUT2, revealed that it is highly expressed during appressorium formation and penetration, and is required for normal appressorium development, surface sensing, and full virulence on rice leaves (Skamnioti and Gurr 2007). Transcript analysis of 14 cutinase genes of $M$. grisea during barley leaf infection indicated the potential for additional functional diver- 
sity (Skamnioti et al. 2008). This suggests a degree of subfunctionalization of cutinase family members in $M$. grisea and, perhaps, other pathogens as well.

Monilinia fructicola forms nonmelanized appressoria for penetration of petals and stage II (immature) fruit, which can lead to quiescent infections in the latter (Lee and Bostock 2007). These appressoria are required for full symptom development on flower petals of Prunus spp. (Lee and Bostock 2006b). In light of evidence for redox-regulation of MfCUT1 expression and of appressorium development (Lee and Bostock 2007), we conducted a more in-depth analysis of MfCUT1 expression and function during infection. Previously, we developed Agrobacterium spp.-mediated transformation and homologous gene replacement in M. fructicola (Lee and Bostock 2006a). A limitation of M. fructicola for gene replacement studies is that it is multinucleate, with a high frequency of nonspecific integrations. We were able to obtain partial disruptants of MfCUTl but unable to obtain homokaryons with the disrupted gene (Lee and Bostock 2006a).

In this study, we assess the potential role for MfCUT1 in brown rot lesion development based on in situ detection of cutinase using the $\beta$-glucuronidase (GUS)-reporter assay, measurement of MfCUT1 transcript levels by semiquantitative reverse-transcriptase polymerase chain reaction (sq-RT-PCR), and comparison of wild-type (WT) and MfCUT1-overexpressing transformants of $M$. fructicola. In addition, we report the genomic sequence of $M f C U T 1$ and flanking regions. The sequence reveals elements within the promoter region that may contribute to cutinase regulation under a changing redox environment. We also show that the expression of MfCUT1 is upregulated under oxidative stress, which has not been reported for fungal cutinases.

\section{RESULTS}

\section{Isolation of $M f C U T 1$ and its flanking regions.}

The MfCUT1 gene was amplified from $M$. fructicola genomic DNA using the primers cutF1 and cutR1, specific for the MfCUT1 cDNA. The PCR reaction yielded an approximately 650 -bp product which, when sequenced, was found to be identical to the cDNA (GenBank accession number AF305598) except for a 63-bp intron located at amino acid 94. Southern hybridization analysis of $\mathrm{BglII}-, \mathrm{XhoI-}$, and HindIII-digested genomic DNA using probe 1 (Supplementary Table 1) revealed a single band from each digestion, consistent with MfCUT1 occurring as a single copy in the $M$. fructicola genome (Supplementary Fig. 1). Based on the Southern hybridization results, $B g l$ II was initially used for inverse PCR (IPCR) to obtain sequences flanking the MfCUT1 gene. The resulting $1.5-\mathrm{kb}$ product was cloned and sequenced. Subsequently, IPCR was performed using Bam HI and XhoI to obtain, in total, the $4.5-\mathrm{kb}$ sequence of MfCUTI and its flanking $5^{\prime}$ and $3^{\prime}$ regions. The IPCR reaction is illustrated in Supplementary Figure 2. A restriction map and sequence are presented in Supplementary Figure 3 (GenBank accession number DQ173196).

\section{Predicted transcriptional binding sites on the $M f C U T 1$ promoter.}

To gain more information about the possible regulation of MfCUT1 expression, the upstream region was analyzed by the Transcription Element Search System (TESS) program using the standard filters. Only domain sequences in the MfCUT1 promoter resulting from this analysis having La/ parameter values of 2.0 were considered to be potential transcription factor binding sites. Potential transcriptional binding sites located on the MfCUT1 promoter region are listed in Supplementary Table 2 and illustrated in Supplementary Figure 4. The tran- scription start site (TSS) located at -153 was defined after the alignment of the 4.5-kb sequence and MfCUT1 cDNA sequence. For transcription initiation, three putative TATA boxes recognized by the TATA box binding protein (TBP) are located between -62 to -19 ; the promoter CCAAT box domain was not found. For carbon metabolic regulation, two carbon catabolite repressor (Cre1) binding sites are located near -500. For nitrogen metabolic regulation, two binding sites for activator of nitrogen-regulated genes (NIT2) are present, one located among the three TATA boxes and the other at position $-1,185$. Six transcription binding sites for a redox-sensitive transcription factor, activator protein-1 (AP-1), are located at positions 1,154 to -243 (Toone et al. 2001). Furthermore, eight binding sites for the glucocorticoid receptor (GR), which interacts with AP-1 directly, are found at positions -979 to -190 . Additional transcription factor binding sites related to fungal development and nutrient metabolism (GCN 4, GAL 4, and abaA) are indicated.

\section{Characterization of MfCUT1-GUS transformants.}

pMfCUT1-GUS was used for Agrobacterium spp.-mediated transformation of $M$. fructicola to generate transformants that expressed the GUS reporter under control of MfCUT1 (Supplementary Fig. 5). In one experiment, a single transformant was generated with pMfCUT1-GUS and approximately 10 transformants were generated using the parent vector pNC1381Xa. This indicates that nptII selection conferred by $\mathrm{pNC} 1381 \mathrm{Xa}$ works well in M. fructicola. When grown in cutinase-inducing medium, the MfCUT1-GUS transformant (designated as strain A2388) but not the WT host strain (MUK-1) expressed blue color after incubation with X-Gluc. Color did not develop when A2388 and MUK-1 were grown on V8 medium in the absence of cutin.

Because M. fructicola is multinucleate and Agrobacterium spp.-mediated transformation often resulted in multiple $\mathrm{T}$ DNA integrations in the $M$. fructicola genome (Lee and Bostock 2006a), A2388 was further purified by protoplast generation. Two protoplast progenies, designated P1 and P2, were subjected to Southern analysis to determine the number of TDNA integrations. Genomic DNA from MUK-1, P1, and P2 was digested with BamHI and HindIII and analyzed by Southern analysis with probes 1 and 2. Probe 1, designed specifically to recognize the $M f C U T 1$ open reading frame (ORF), detected MfCUT1 in both MUK-1 and the A2388 protoplast progenies. Probe 2 is specific to the GUS ORF and, thus, only recognizes the MfCUT1-GUS construct. As expected, probe 1 detected two fragments and probe 2 detected one fragment following XhoI or HindIII digestion (Supplementary Fig. 6). These results indicate that the MfCUTI-GUS construct integrates as a single copy and as a single integration among protoplast-purified progenies. The parent transformant A2388 and the two progenies P1 and P2 each appear to carry two copies of MfCUT1, as estimated from the band densities. The protoplast-purified MfCUT1-GUS strains P1 and P2 were identical in appearance to MUK-1 when grown on Sclerotinia minimal medium (SMM) or on rich media such as V8 agar or potato dextrose agar. Furthermore, no differences were noted between MUK1, A2388, P1, and P2 with respect to spore germination and appressorium formation (data not shown).

To determine whether expression of the MfCUT1-GUS fusion protein in transformants was under the regulation of the MfCUT1 promoter, A2388 was cultured in cutinase-inducing medium with or without the addition of glucose. GUS activity with X-Gluc as substrate was evident in culture filtrates, hyphae, and microconidia and microconidiophores after the cultures were incubated in cutinase-inducing medium (Fig. 1A and B). No blue color was detected in cutinase-inducing medium 
amended with $2 \%$ glucose (data not shown). Also, no blue color was detected in MUK-1 cultures in cutinase-inducing medium. A2388 did not express GUS in V8 broth, potato dextrose broth, and SMM broth, indicating that expression of the MfCUT1-GUS fusion protein is cutin inducible and glucose repressible, consistent with the regulated expression of

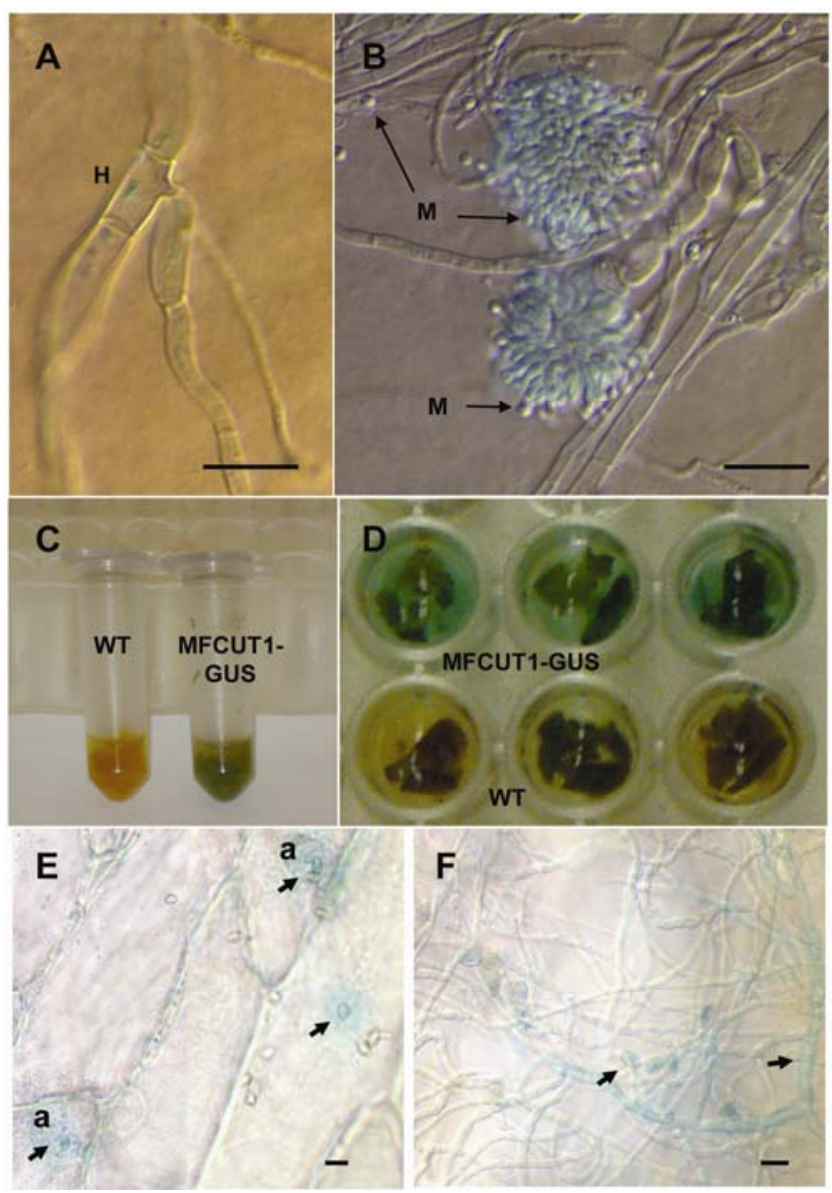

Fig. 1. $\beta$-Glucuronidase (GUS) expression in Monilinia fructicola MfCUT1-GUS strain A2388 under cutinase-inducing conditions. A, Culture (14-day) on Czapek-Dox-glucose (mCZ)-cutin medium with GUS expression in hyphal vesicles $(\mathrm{H}) ; \mathbf{B}$, microconidia $(\mathrm{M})$ and conidiophores on cutin medium; C, peach fruit tissue (cv. Dr. Davis) at 4 days postinoculation (dpi); D, apple fruit tissue (cv. Granny Smith; 4 dpi) inoculated with the wild type (WT) or a protoplast-purified progeny strain (P1) derived from A2388; E, onion epidermis at $4 \mathrm{~h}$ postinoculation (hpi); and $\mathbf{F}$, peach flower petal ( $24 \mathrm{hpi}$ ). No GUS activity is observed with the WT strain. The X-Gluc-stained hyphae, conidia, and appressoria (a) are indicated (arrows). Bar in panels A, B, E, and F indicates $10 \mu \mathrm{m}$.
MfCUT1 in WT strains reported previously (Bostock et al. 1999; Wang et al. 2002). Therefore, GUS activity in the MfCUT1-GUS strain provides a reasonable measure of MfCUT1 expression and was used in subsequent experiments.

\section{MfCUT1 is expressed}

during infection and lesion development.

Peach and apple fruit inoculated with MUK-1 or with A2388 developed similar brown rot symptoms. Four days after inoculation, the infected tissues were excised and stained with $\mathrm{X}-\mathrm{Gluc}$, with a positive reaction developing in the A2388infected tissues but not in tissue infected by MUK-1 (Fig. 1C and D). M. fructicola can form appressoria and infect Prunus flower petals and onion epidermal layers (Lee and Bostock 2006b). MfCUT1 expression also was detected by GUS activity during penetration of onion epidermis (Fig. 1E). Prunus flower petals were inoculated with conidia of MUK-1 or with MfCUT1-GUS transformants and the infected petals were then incubated with X-Gluc at various times after inoculation $(0,1$, $2,3,4,6$, and $24 \mathrm{~h}$ ). GUS activity was apparent at $24 \mathrm{~h}$ postinoculation (hpi) with A2388, in close proximity to hyphae and conidia in the tissue (Fig. 1F). No GUS activity was detected at the early stages of infection ( 0 to $6 \mathrm{~h}$; data not shown).

sq-RT-PCR (Choquer et al. 2003) also confirmed MfCUT1 expression during $M$. fructicola infection on almond and peach flower petals. MfCUTI messenger (m)RNA was detected in inoculated almond petals at 5 and 48 hpi (Fig. 2A). A 10-fold higher level of mRNA for the internal control, TUB2, was detected at 48 than at 5 hpi ( 30 cycles), consistent with the probability that a greater amount of fungal biomass is present in the infected tissue at the latter time point. The ratio of $M F C U T 1$ to TUB2 was higher at 5 hpi ( 0.44 for 40 cycles) than at 48 hpi ( 0.18 for 25 cycles), although the total amount of mRNA was much lower at the earlier time point.

In peach petals, MfCUT1 mRNA was detected at 5 hpi and at all time points until the conclusion of the experiment (46 hpi). The ratio of $M f C U T 1 \mathrm{mRNA}$ to $T U B 2 \mathrm{mRNA}$ peaked at 9 hpi and then declined and leveled off between 22 to $46 \mathrm{hpi}$ (Fig. 2B).

\section{Cutinase overexpressors produce larger lesions on Prunus flower petals than the WT.}

In light of the evidence for early expression of MfCUT1 during infection of flower petals, we sought to determine whether a transformant altered in MfCUT1 expression displayed a corresponding change in virulence relative to the WT. Prunus flower petals provide an ideal tissue for discerning subtle differences among $M$. fructicola strains in their ability for direct penetration because of the absence or infrequency of stomata,

Table 1. Lesion areas on flower petals resulting from infection by Monilinia fructicola strain MUK-1 (wild type [WT]) or the MfCUT1 overexpressor strains $\mathrm{P} 1$ and $\mathrm{P} 2$

\begin{tabular}{|c|c|c|c|c|c|c|}
\hline \multirow[b]{2}{*}{ Cultivar } & \multirow[b]{2}{*}{$\operatorname{Exp}^{b}$} & \multirow[b]{2}{*}{$n^{\mathrm{c}}$} & \multicolumn{3}{|c|}{ Necrotic area $\left(\mathrm{mm}^{2}\right)^{a}$} & \multirow[b]{2}{*}{ Significance $(P \text { value })^{d}$} \\
\hline & & & MUK-1 (WT) & P1 (MfCUT1-GUS) & P2 (MfCUT1-GUS) & \\
\hline Nectarine cv. Flavor Top & 1 & 37 & 0.0 & 1.6 & - & $<0.01$ \\
\hline \multirow[t]{2}{*}{ Peach cv. Loadel } & 2 & 33 & 3.2 & 9.5 & - & $<0.0001$ \\
\hline & 3 & 35 & 10.2 & 15.6 & - & $<0.01$ \\
\hline \multirow[t]{2}{*}{ Cherry } & 4 & 27 & 4.4 & 14.2 & - & $<0.05$ \\
\hline & $\ldots$ & $\ldots$ & 4.4 & - & 11.0 & $<0.05$ \\
\hline
\end{tabular}

\footnotetext{
a Tabular entries under MUK-1 and P1 or P2 represent the average necrotic area 15 to 22 h postinoculation (hpi) for peach petals and 36 hpi for cherry petals, as measured by digital image analysis. GUS $=\beta$-glucuronidase.

${ }^{\mathrm{b}}$ For experiments 1 to 3 , each petal was inoculated with both strains, with the strains applied on opposite sides of the midvein. Inoculum was applied as a 5- $\mu$ d drop containing 250 conidia. For experiment 4, due to the small size of cherry petals, each petal was inoculated with a single strain as a 5- $\mu$ drop containing 500 conidia; nine petals for each strain with three replicates.

c Sample size.

${ }^{\mathrm{d}}$ Observed $P$ values are based on a paired $t$ test for experiments 1 to 3 and analysis of variance (single factor) for experiment 4 .
} 
surface fissures, and broken trichomes, which are avenues for indirect penetration in fruit. In paired inoculations of peach, nectarine, and cherry flower petals, lesion size at 15-22 hpi was significantly greater $(p<0.05)$ in petals inoculated with P1 or P2 than with MUK-1 (Table 1; Fig. 3). The expression of
MfCUT1 was determined by sq-RT-PCR and by cutinase activity in culture filtrates (Bostock et al. 1999; Wang et al. 2000). P1 and P2 produced a twofold higher level of MfCUT1 transcripts than MUK-1 using 16-HHA as an inducer for cutinase expression (Fig. 4). However, we did not detect a correspond-
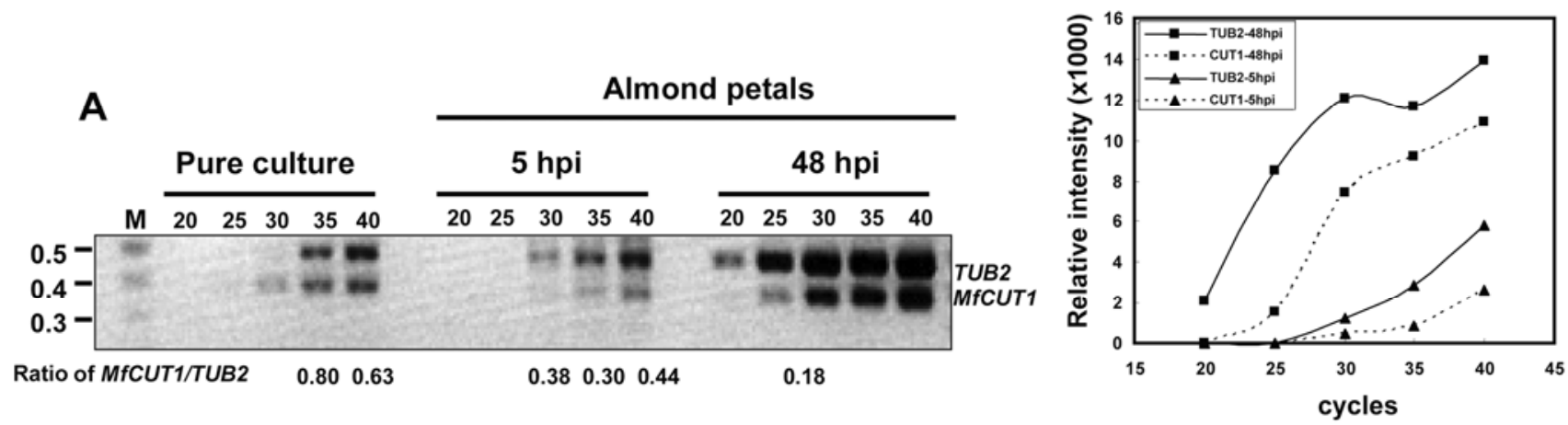

B

Peach petals

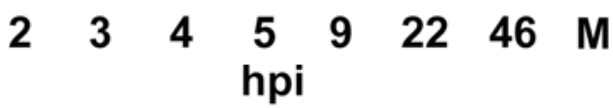
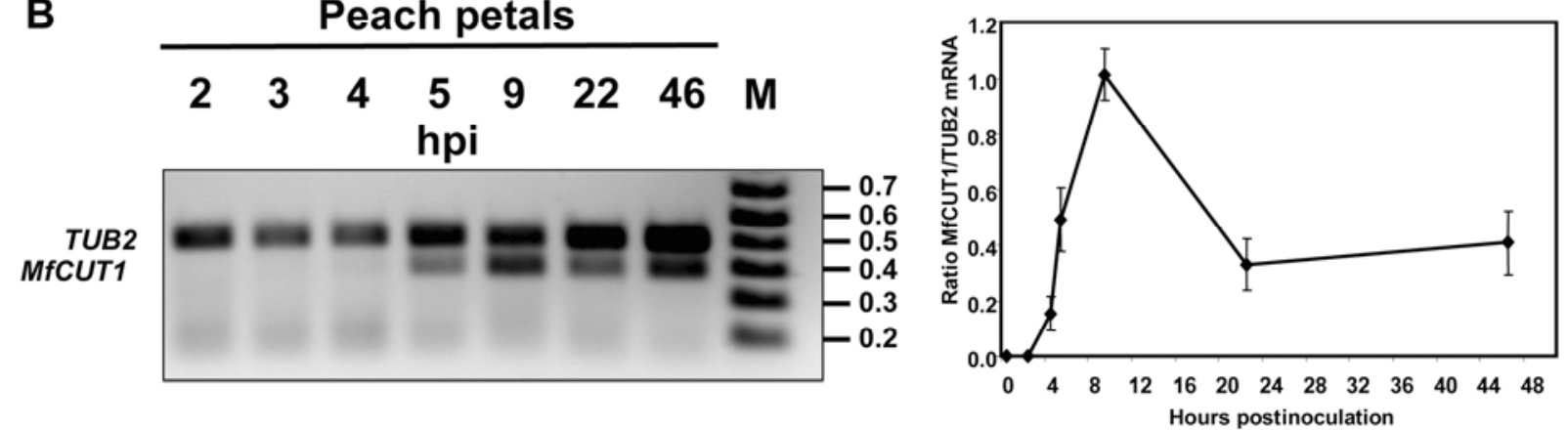

Fig. 2. Detection of MfCUT1 expression in Monilinia fructicola-infected almond and peach flower petals by semiquantitative reverse-transcriptase polymerase chain reaction (sq-RT-PCR). A, MfCUT1 and TUB2 expression in a cutinase-induced culture and in almond petals infected with MUK-1 (wild-type strain) at 5 and $48 \mathrm{~h}$ postinoculation. Samples of the PCR reaction mixture were collected at the cycle number indicated above each lane. The ratios of MfCUT1 to TUB2 PCR products amplified in the exponential stage are indicated below each lane of the gel where appropriate. Graph is a plot of the relative band intensity versus PCR cycles to show the amplification pattern for each sample. B, Representative gel with reaction products from RT-PCR (40 cycles) performed as above with total RNA extracted from peach petals inoculated with M. fructicola at the indicated times. Graph illustrates MfCUT1 transcript abundance relative to TUB2 transcript abundance following inoculation. Mean and standard error of four determinations from two experiments are indicated. M, DNA size standards indicated in kilobases.

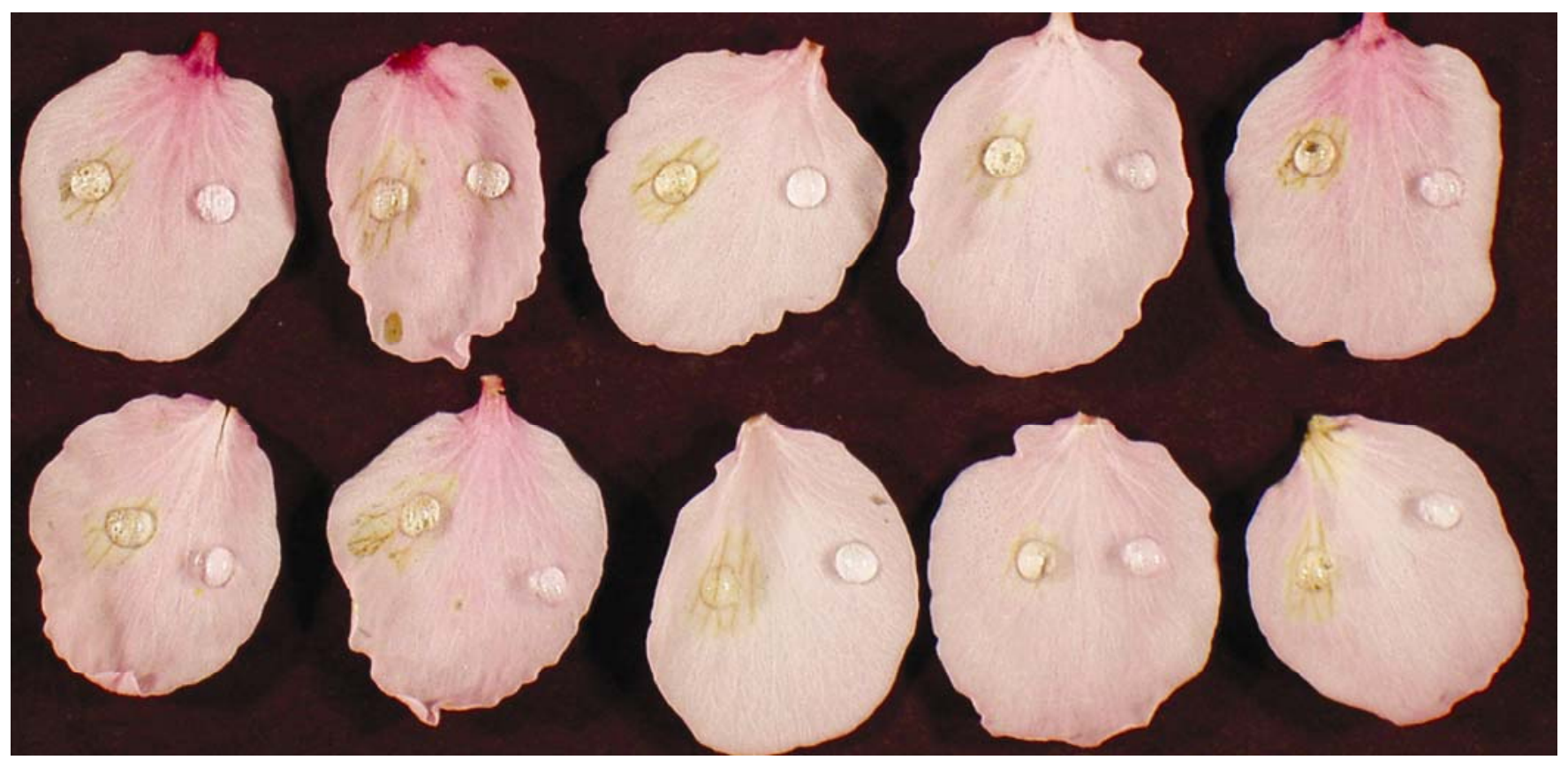

Fig. 3. Brown rot lesion development on peach petals (cv. Loadel) caused by Monilinia fructicola wild-type strain MUK-1 (right panel of petal) and by the MfCUT1- $\beta$-glucuronidase overexpressor transformant P1 (left panel of petal) at $18 \mathrm{~h}$ after inoculation. 
ing difference between P1 or P2 and MUK-1 in extracellular cutinase activity as determined by $\rho$-nitrophenyl butyrate (PNB) hydrolysis in cultures sampled $24 \mathrm{~h}$ after induction with 16-HHA or with apple cutin (data not shown).
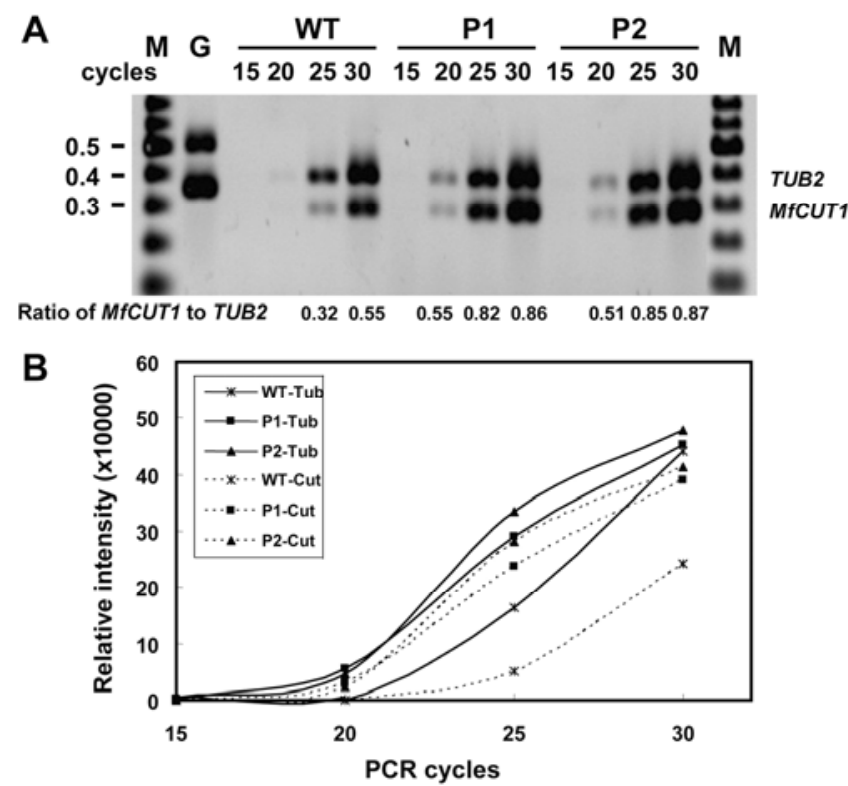

Fig. 4. Transcript analysis for MfCUT1 expression of Monilinia fructicola wild-type strain (WT) and MFCUT1- $\beta$-glucuronidase strains (P1 and P2) in cutinase-inducing medium. M. fructicola mycelia were harvested for RNA extraction after shifting to cutinase-inducing medium for an additional $24 \mathrm{~h}$ of incubation. A, MfCUT1 expression analyzed by semiquantitative reverse-transcriptase polymerase chain reaction (sq-RT-PCR). Samples were collected at the indicated number of PCR cycles. Ratios of MfCUT1 to TUB2 transcripts based on band intensity are indicated below the gel. B, Plot of the relative band intensity versus PCR cycles to show the amplification pattern for each sample. G, genomic DNA used as template in the PCR as a control.
To assess the potential for GUS to increase virulence of the transformants, peach, nectarine, and apple fruit were wounded and inoculated with MUK-1 (WT) or with P1 or P2. Although wounding eliminates the barrier presented by the cuticle, the MfCUT1-GUS fusion protein is expressed in the presence of fruit tissue (Fig. 1C). Lesion size in wounded apple and nectarine fruit inoculated with $\mathrm{P} 1$ or $\mathrm{P} 2$ was not different from the WT (data not shown). In wounded peach fruit, lesion size was slightly less in fruit inoculated with the MfCUT1-GUS transformants relative to the WT ( $\leq 7 \%$ at $72 \mathrm{hpi}$ ) (data not shown).

\section{Mfcut1 expression is enhanced by oxidative stress.}

Because several potential AP-1 binding sites are present in the upstream region of $M f C U T 1$, and in light of diminished cutinase expression in the presence of antioxidants (Lee and Bostock 2007), we examined the effect of oxidative stress on $M f C U T 1$ expression. MfCUT1 transcripts were detected by sqRT-PCR and RNA gel-blot analysis after treatment of the cultures with $\mathrm{H}_{2} \mathrm{O}_{2}$. Expression of MfCUT1 was enhanced by $\mathrm{H}_{2} \mathrm{O}_{2}$ at concentrations of 0.1 to $0.5 \mathrm{mM}$. Transcript levels in cultures treated with $0.25 \mathrm{mM} \mathrm{H}_{2} \mathrm{O}_{2}$ for $24 \mathrm{~h}$ were approximately 1.7 -fold higher than control cultures (Fig. 5). There was no effect of $\mathrm{H}_{2} \mathrm{O}_{2}$ on MfCUT1 expression at $12 \mathrm{~h}$, the earliest time point sampled (data not shown). $\mathrm{H}_{2} \mathrm{O}_{2}$ concentrations of $1 \mathrm{mM}$ or greater inhibited the growth of $M$. fructicola and reduced ribosomal RNA yields. Analysis by sq-RT-PCR provided results similar to RNA gel-blot analysis (Fig. 5). The experiment was performed twice with nearly identical results.

\section{DISCUSSION}

In this study, we used a GUS reporter gene fused with the MfCUT1 ORF and promoter to demonstrate the regulated expression of cutinase during fungal growth and brown rot lesion development in plant tissue. Strains carrying the GUS fusion had two copies of MfCUT1 and, thus, provided a means to evaluate a possible gene dosage effect of MfCUT1 in viru-
A
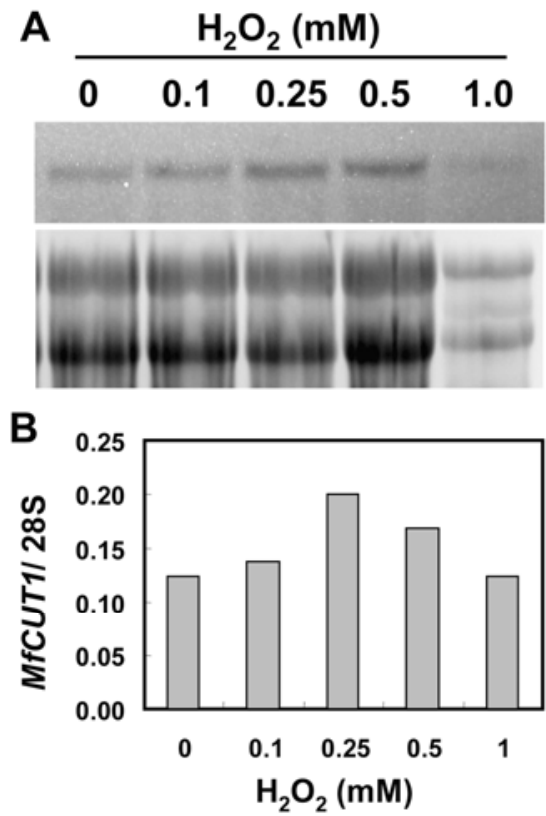

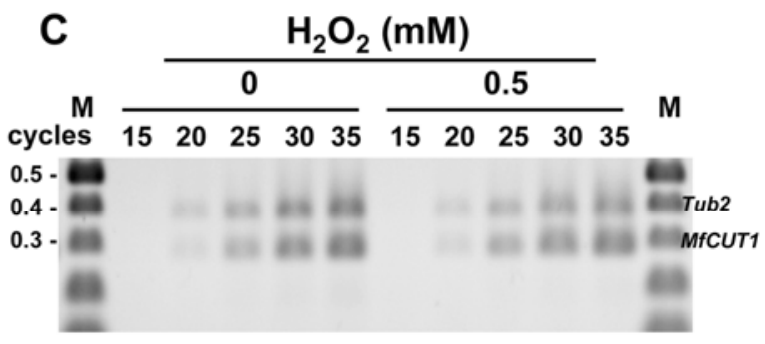

D

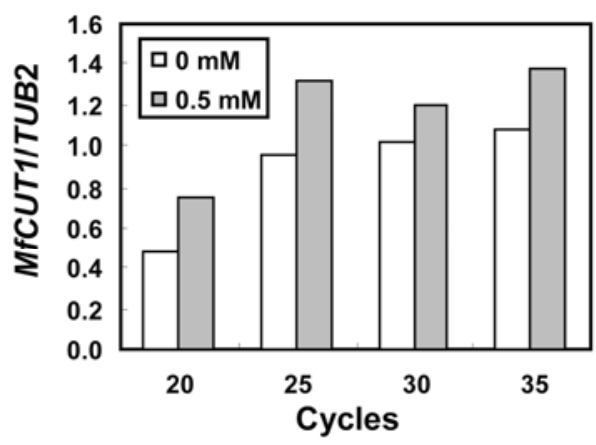

Fig. 5. Expression of $M f C U T 1$ in cultures $24 \mathrm{~h}$ after treatment with $\mathrm{H}_{2} \mathrm{O}_{2}$. A, Upper panel, RNA gel blot analysis of $M f C U T 1$ in total RNA from mycelia treated with $\mathrm{H}_{2} \mathrm{O}_{2}$. Lower panel, ribosomal (r)RNA stained with ethidium bromide (20 $\mu \mathrm{g}$ of total RNA per lane). B, Expression of $M f C U T 1$ relative to $28 \mathrm{~S}$ rRNA as determined by the intensity of each band shown in A. C, Analysis of MfCUT1 expression by semiquantitative reverse-transcriptase polymerase chain reaction (sq-RT-PCR) using $20 \mathrm{ng}$ of total RNA from mycelia treated with $0.5 \mathrm{mM} \mathrm{H}_{2} \mathrm{O}_{2}$. PCR products were collected for analysis at the indicated PCR cycles. D, Relative expression level of MfCUT1 to TUB2 based on the intensity of each band shown in C. $28 \mathrm{~S}$ RNA and TUB2 served as internal controls in the RNA gel blot and sq-RT-PCR, respectively. 
lence. Overexpression of MfCUT1 increased brown rot lesion size in peach, nectarine, and cherry flower petals relative to the WT strain, supporting a role for cutinase in virulence of $M$. fructicola on these tissues.

MfCUT1 occurs as a single copy in the M. fructicola genome, and no closely related genes were detected in Southern hybridization analysis, even under low-stringency washes at $45^{\circ} \mathrm{C}$ (data not shown). However, several esterases with cutinase activity besides MfCUT1 are produced by M. fructicola in culture under inducing conditions (Wang et al. 2000). Although these have not been isolated and further characterized, the predominance and pattern of expression of MfCUT1 suggest that MfCUT1 is functionally different (Wang et al. 2000, 2002). Analysis of the genomic MfCUT1 sequence indicates the presence of one intron, similar to cutinase genes from other phytopathogenic fungi, which often contain one or two introns (Ettinger et al. 1987; Van Der Vlugt-Bergmans et al. 1997).

Analysis of the MfCUT1 promoter region revealed the absence of a CCAAT box, which has also been reported to be absent in other cutinase genes (Soliday et al. 1989). While predicting the putative transcription binding domains in the MfCUT1 promoter, we were particularly interested in two types of domains. One type is represented by the two continuous palindromic domains found in the promoters of Fusarium solani $\mathrm{f}$. sp. pisi cutinase genes. These are the only promoters that have been studied in some detail with respect to transcriptional regulation. Two transcription binding proteins (CTF1 $\alpha$ and $1 \beta$ ) bind to palindromes 1 and 2, respectively, and regulate inducible and constitutive expression. However, the palindrome binding site, $5^{\prime}-\mathrm{GCC}(\mathrm{n} 2) \mathrm{GGC}-3^{\prime}$, is located within a poly $\mathrm{G}$ region of the F. solani f. sp. pisi promoter, which is not found in the promoter region of MfCUT1. This indicates that the regulatory domains for inducible expression of $M f C U T 1$ are different from those of the $F$. solani $\mathrm{f}$. sp. pisi cutinase genes.

Transcription binding sites involved in redox regulation are also of interest because MfCUT1 is negatively regulated by host phenols and other compounds that influence cellular redox states (Bostock et al. 1999; Wang et al. 2002; Lee and Bostock 2007). Six putative AP-1 binding sites are located in the MfCUT1 promoter region. The AP-1 transcription factor is a central component of signal transduction pathways coupled to oxidative stress management and metal tolerance in mammalian and yeast cells (Alarco et al. 1997; Primiano et al. 1997). When cells experience oxidative stress, redox signaling cascades are triggered, which includes activation of redoxregulated proteins and gene expression. In yeast, the expression of AP- 1 is typically induced by $\mathrm{H}_{2} \mathrm{O}_{2}$. AP- 1 activates the expression of its target genes, whose promoter regions contain the AP-1 binding sites (Arrigo 1999). Chlorogenic and caffeic acids will change the electrochemical redox potential of $M$. fructicola cultures and alter intracellular levels of glutathione (GSH), a major cellular antioxidant (Lee and Bostock 2007). MfCUT1 expression is correlated to changes in intracellular GSH levels, and GSH reductase is a key enzyme in managing redox status in response to caffeic acid. We have isolated an AP-1-like gene in M. fructicola and functional characterization of this gene is underway (C. M. Chiu and M. H. Lee, unpublished).

M. fructicola is a necrotrophic pathogen, as are the related Sclerotiniaceae species Botrytis cinerea and Sclerotinia sclerotiorum. In the case of $B$. cinerea and $S$. sclerotiorum, growth and symptom development on Arabidopsis is positively correlated with levels of $\mathrm{H}_{2} \mathrm{O}_{2}$ (Govrin and Levine 2000). We found that $\mathrm{H}_{2} \mathrm{O}_{2}$ increases the expression of MfCUT1 in culture. This suggests that $\mathrm{H}_{2} \mathrm{O}_{2}$ generated during the plant response may actually enhance infection by $M$. fructicola through an increase of MfCUT1 expression. Antioxidants, including reduced gluta- thione, $\mathrm{N}$-acetyl cysteine, and ascorbic acid, reduced the expression of MfCUT1 (Wang et al. 2002 and unpublished data). Together, these data indicate that the expression of MfCUT1 is altered, in part, by changes in cellular redox. The role of reactive oxygen species in the expression of virulence and pathogenicity genes in necrotrophs and how factors such as AP-1 may participate in gene regulation is a fertile area for further investigation.

Other important putative transcription factor binding sites present in the $M f C U T 1$ promoter regions such as $C r e 1$ could be involved in glucose catabolite repression of MfCUT1 expression. Several fungal glucose repressors, including CRE1 of $S$. sclerotiorum, bind to the consensus sequence $5^{\prime}-\mathrm{SYGGRG-3'}$ in the promoter of glucose-regulated genes (Cubero and Scazzocchio 1994; Strauss et al. 1995; Vautard et al. 1999). The presence of NIT2 in the MfCUT1 promoter region indicates that starvation in the form of nitrogen limitation may be involved in the regulation of MfCUT1 expression, because NIT2 mediates the repression of its target genes when primary nitrogen sources are available (Premakumar et al. 1980; Marzluf 1997).

The gusA fusion vector pMfCUT1-GUS created in this study retained the nptII selectable marker from $\mathrm{pNC1381-Xa}$ and functioned well for selecting transformants. pNC1381-Xa could be useful for analyses of other genes and their promoters in $M$. fructicola and related filamentous fungi. Because $M$. fructicola is multinucleate and transformants generated by Agrobacterium spp.-mediated transformation often carried multiple T-DNA integrations, the original MfCUT1-GUS transformant was further purified by protoplast regeneration. The resulting transformants carried a single copy of MfCUT1-GUS under control of the MfCUT1 promoter, in addition to the endogenous MfCUT1. Protoplasts, perhaps as a result of their reduced size, have been reported to carry fewer nuclei than the undigested cells from which they are derived (da Silva and Paccola-Meirelles 2001). This indicates that protoplast regeneration can provide an alternative method for generating homokaryons from a heterokaryotic background, as in M. fructicola.

MfCUT1-GUS hyphae and microconidia expressed GUS activity in media containing cutin and not in the presence of glucose or sucrose. Although $M$. fructicola microconidia are nongerminable and their role in the life cycle is unclear, GUS activity is expressed strongly in these uninucleate cells and their conidiophore phialides, indicating that microconidia are metabolically active and capable of expressing cutinase. GUS activity also was detected within 4 hpi in appressoria formed on onion epidermal layers and in later stages of infection of Prunus and apple tissue. However, GUS activity was not detected in conidia that were harvested from cultures grown on V8 agar and then transferred to fresh medium containing cutin or in the germ tubes or appressoria that developed from them on this medium (data not shown). Perhaps other internal signals, such as stored carbohydrate reserves, remained at sufficient levels to override the cutin signal from the second "inducing" medium. This also may explain, in part, the absence of detectable GUS activity during early stages of infection on Prunus petals. Overall, the pattern of expression suggests tight and complex regulation of cutinase expression in $M$. fructicola, expression that is likely dependent on a delicate balance of positive and negative effectors in culture and within a specific host context.

sq-RT-PCR provided a more sensitive measure than GUS assay of MfCUT1 expression during infection and colonization of flower petals. Penetration of almond petals by $M$. fructicola occurs between 3 and $9 \mathrm{hpi}$, with initial symptoms apparent 10 to $14 \mathrm{hpi}$ and thorough colonization of the petal occurring 24 to 48 hpi (Lee and Bostock 2006b). Thus, samples for sq-RTPCR were taken at 5 and 48 hpi. sq-RT-PCR provided strong 
evidence for early expression of MfCUT1 and validated the GUS activity results for late stage infection. The timing of MfCUT1 expression as detected by sq-RT-PCR is consistent with the involvement of cutinase in the initial penetration of almond petals as well as cutinase having an important function in later stages of colonization, perhaps in the hydrolysis of cutin and cutin-like substrates to provide a source of carbon.

The enhanced virulence of the protoplast-purified MfCUT1GUS transformants (P1 and P2), which carry two copies of MfCUT1, provides evidence for a contribution of MfCUT1 to infection of flower petals by $M$. fructicola (Table 1). The increased virulence of the transformants may result from a dosage effect of $M f C U T 1$, as supported by the in vitro transcript abundance following induction with a synthetic cutin monomer (Fig. 4). The results with wound-inoculated peach, nectarine, and apple fruit suggest that the presence of GUS itself does not contribute to the virulence of the MfCUT1-GUS transformants. However, it is also possible that the MfCUT1-GUS construct integrated at a site to alter virulence by a mechanism unrelated to $M f C U T 1$ expression. To address this, we isolated the insertion site using thermal asymmetric interlaced-PCR. Eighteen nucleotides that are not present in the pMFCUT1-GUS vector were used to blast the National Center for Biotechnology Information database. No specific function could be attributed to this sequence and the sequence has no homology with any known virulence or pathogenicity factors in other plant pathogens. Because there are only a few $M$. fructicola genes recorded in public databases at this time, we cannot exclude the possibility of the insertion site including a specific negative regulator of virulence. It is also possible that epigenetic factors associated with transformation results in increased virulence; however, this seems unlikely because growth rate, germination, and appressorium formation were not affected in the transformants relative to the WT.

M. fructicola is multinucleate and a very difficult species from which to obtain homokaryotic gene disruptants. In the absence of a clean knock-out mutant, we were unable to definitively address the issue of the cutinase encoded by MfCUT1 as having a critical role for penetration or establishment of an infection. Nonetheless, our previous study illustrated how the redox state can influence formation of appressoria and expression of both MfCUT1 and the M. fructicola polygalacturonase MfPGI and subsequent disease development (Lee and Bostock 2007). Thus, MfCUT1 is likely one of a suite of co-regulated factors contributing to penetration and invasive growth.

M. fructicola works well with Agrobacterium spp.-mediated and protoplast transformation (Lee and Bostock 2006a) and, thus, is amenable to alternative molecular genetic approaches for functional analyses such as overexpression and, possibly,
RNA-mediated gene silencing (Patel et al. 2008). To our knowledge, this is the first report that assesses the contribution of a potential pathogenicity or virulence factor in Monilinia spp. using transformation and in situ expression.

\section{MATERIALS AND METHODS}

\section{Strains, plasmids, and cultivation.}

A list of the fungal and bacterial strains and plasmids used in this study is presented in Table 2. M. fructicola MUK-1 is a single-spore isolate from infected peach fruit from a local orchard in California (Bostock et al. 1999) and was used throughout this work. Cultures were maintained and grown on clarified V8 (cV8) agar plates at room temperature for 1 week prior to use for transformation and genomic DNA isolation. Transformation of $M$. fructicola was performed as previously described (Lee and Bostock 2006a). SMM (Waksman 1988) provided a basal medium for fungal transformation, and SMM containing G-418 sulfate (SMMG50; A. G. Scientific, Inc., San Diego, CA, U.S.A.) at $50 \mu \mathrm{g} / \mathrm{ml}$ was used to select and maintain transformants (Pratt and Aramayo 2002). Agrobacterium tumefaciens AGL.1 (Hellens et al. 2000) was used for transformation experiments and was maintained in AMM medium (Bundock and Hooykaas 1996) containing spectinomycin $(50 \mu \mathrm{g} / \mathrm{ml})$ and streptomycin $(50 \mu \mathrm{g} / \mathrm{ml})$ at $28^{\circ} \mathrm{C}$. Escherichia coli XL1-Blue (Stratagene, La Jolla, CA, U.S.A.) was used for manipulations of all plasmids used in this study. Binary vector pCAMBIA 1381-Xa (CAMBIA, Canberra, Australia) was used as a backbone for constructing the MfCUT1-GUS fusion vector. Plasmid pART27 (Gleave 1992) was provided by L. Ciuffetti (Oregon State University) and was used as template to amplify the nptII cassette. All fungal strains were stored in $10 \%$ dimethyl sulfoxide at $-75^{\circ} \mathrm{C}$ for long-term storage.

\section{Genomic DNA isolation.}

$M$. fructicola strains were grown on cellophane on top of cV8 agar for 7 days at room temperature. Mycelia were collected from the cellophane and stored at $-75^{\circ} \mathrm{C}$ for DNA isolation. Genomic DNA was isolated by a procedure described by E. W. Boehm, which is available online. Mycelia (1 g) was ground into a powder in liquid nitrogen and transferred to a centrifuge tube with $10 \mathrm{ml}$ of lysis buffer $(100 \mathrm{mM}$ Tris $[\mathrm{pH}$ 8.0 ], $10 \mathrm{mM}$ EDTA, proteinase $\mathrm{K}$ at $100 \mu \mathrm{g} / \mathrm{ml}, 2 \%$ sodium dodecyl sulfate [SDS], and 1\% 2-mercaptoethanol) (Ma et al. 2001). The tube was incubated at $60^{\circ} \mathrm{C}$ for $1 \mathrm{~h}$, inverting the tubes every $10 \mathrm{~min}$ to $\mathrm{mix}$ the contents. After adjusting the $\mathrm{NaCl}$ concentration to $1.4 \mathrm{M}$ and adding 0.1 volume of $10 \%$ hexadecyltrimethyl ammonium bromide (\#H-5882; SigmaAldrich, St. Louis), the mixture was incubated a further $10 \mathrm{~min}$

Table 2. List of fungal and bacterial strains and plasmids used in the present study

\begin{tabular}{|c|c|c|}
\hline Strains and plasmids & Relevant characteristics & Reference, source \\
\hline \multicolumn{3}{|l|}{ Monilinia fructicola } \\
\hline MUK-1 & Wild type, isolated from peach & Bostock et al. 1999 \\
\hline A2388 & MfCUT1-gusA transformant of MUK-1; nptII (G418 resistant) & This work \\
\hline P1 & Protoplast-purified homokaryon with $M f C U T 1$-gusA, derived from A2388 & This work \\
\hline P2 & Protoplast-purified homokaryon with MfCUT1-gusA, derived from A2388 & This work \\
\hline \multicolumn{3}{|c|}{ Agrobacterium tumefaciens } \\
\hline AGL.1 & C58 RecA pTiBo542DTDNA & Hellens et al. 2000 \\
\hline \multicolumn{3}{|l|}{ Escherichia coli } \\
\hline XL1-Blue & 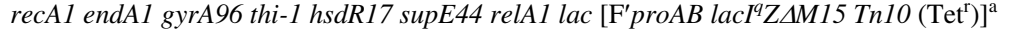 & Stratagene, La Jolla, CA, U.S.A. \\
\hline \multicolumn{3}{|l|}{ Plasmids } \\
\hline pART27 & Source of $n p t I I$ & Gleave et al. 1992; L. Ciuffetti \\
\hline pCAMBIA1381-Хa & hptII Kan gusA; Backbone for MfCUT1-gusA fusion vector; & CAMBIA, Canberra, Australia \\
\hline pNC1381-Xa & Same as pCAMBIA $1381-\mathrm{Xa}$ but $h p t I I$ was replaced with $n p t I I$ from pART27 & This work \\
\hline pMfCUT1-GUS & Same as pNC1381-Xa and contains $M F C U T 1$ promoter and open reading frame & This work \\
\hline
\end{tabular}

${ }^{\mathrm{a}} \mathrm{Tet}^{\mathrm{r}}=$ tetracycline resistant. 
at $65^{\circ} \mathrm{C}$. The heat-treated lysis mixture was thoroughly mixed with 1 volume of chloroform/isoamyl alcohol (24:1) and incubated on ice for $30 \mathrm{~min}$. After centrifugation at $20,000 \times g$ for $10 \mathrm{~min}$ at $4^{\circ} \mathrm{C}$, the aqueous phase was collected and the DNA precipitated by 0.6 volume of isopropanol and 0.5 volume of 5 $\mathrm{M}$ ammonium acetate. The tubes were centrifuged as described previously and the resulting DNA pellets were washed with $70 \%$ ethanol twice and dissolved into $100 \mu \mathrm{l}$ of Tris-EDTA buffer with RNase $(20 \mu \mathrm{g} / \mathrm{ml})$ at $4^{\circ} \mathrm{C}$ overnight.

\section{Isolation of $M f C U T 1$ and its flanking regions.}

Primers cutF and cutR were designed based on the MfCUTI cDNA sequence (GenBank accession number AF305598). $M$. fructicola genomic DNA, isolated as described above, was used as template and the PCR with these primers was performed for 25 cycles at $94^{\circ} \mathrm{C}$ for $30 \mathrm{~s}, 55^{\circ} \mathrm{C}$ for $30 \mathrm{~s}$, and $72^{\circ} \mathrm{C}$ for $1 \mathrm{~min}$, with an additional 7 -min extension at $72^{\circ} \mathrm{C}$. A single PCR product was obtained, gel purified, and sequenced. To isolate the MfCUT1 flanking regions, IPCR was performed as described (Sambrook and Russell 2001). Genomic DNA (1 g) was digested completely by $B g l \mathrm{II}, \mathrm{BamHI}$, or XhoI. The digested DNA was self-ligated using T4 DNA ligase (Promega Corp., Madison, WI, U.S.A.). After phenol extraction and ethanol precipitation, the self-ligated DNA was used as template DNA to amplify MfCUT1 flanking regions by using the KOD HiFi polymerase kit (Novogen, Madison, WI, U.S.A.). The PCR program was performed according to the manufacturer's instructions. The PCR products were gel purified and sequenced or further amplified by nested PCR and sequenced.

\section{MfCUT1-GUS fusion construct and fungal transformation.}

A fusion vector with the GUS gene as a reporter for MfCUT1 expression was created from pCAMBIA 1381-Xa. The hygromycin B phosphotransferase gene (hptII) with the $35 \mathrm{~S}$ promoter inside the T-DNA of pCAMBIA 1381-Xa was replaced with the neomycin phosphotransferase (nptII) cassette, which was amplified from pART27 using the KOD polymerase with primers nptII-Apa and nptII-Xho. This process resulted in a vector called pNC1381-Xa. Also, a promoterless, non-intron gus A gene (N358Q, without an initiation codon) in three reading frames from pCAMBIA1381-Xa was retained in pNC1381Xa. An approximately 1,200-bp upstream region along with the ORF of MfCUT1 was amplified by the KOD polymerase from genomic DNA with primers HindIII-78 and 2388-SpeI. A 2.4-kb PCR fragment was obtained and cloned into HindIII and SpeI sites of pNC1381Xa. This resulted in a binary vector, pMfCUT1-GUS, which carried the MfCUT1GUS fusion construct. pMfCUT1-GUS was transferred into $A$. tumefaciens AGL.1 by electroporation, and the bacteria carrying the pMfCUT1-GUS were then used for transformation (Lee and Bostock 2006a). The optical density of bacterial cells used for co-cultivation was 0.3 at $620 \mathrm{~nm}$.

\section{Protoplast production and regeneration.}

The MfCUT1-GUS strain A2388 was further purified by protoplasting in an attempt to generate homokaryons. To prepare protoplasts, $M$. fructicola conidia $\left(1 \times 10^{7}\right)$ were inoculated into a 500-ml flask with $100 \mathrm{ml}$ of modified SMM broth that included $0.5 \times \mathrm{SMM}$ salts and $1 \%$ glucose. The flasks were incubated at room temperature for $16 \mathrm{~h}$ with shaking at $100 \mathrm{rpm}$. Cultures were collected by filtration and washed once with $200 \mathrm{ml}$ of sterile water and then once with $0.5 \times \mathrm{KC}$ buffer $\left.(0.6 \mathrm{M} \mathrm{KCl} \text { and } 50 \mathrm{mM} \mathrm{CaCl})_{2}\right)$. During the preparation of the cell-wall digestion solution, the washed mycelia were incubated at $4{ }^{\circ} \mathrm{C}$. The cell-wall digestion suspension contained 3.5 volumes of Driselase (KC buffer at $10 \mathrm{mg} / \mathrm{ml}$; catalog \#0465-1; Interspex Products, Inc., San Mateo, CA, U.S.A.) and 1 volume of lysing enzymes (KC buffer at $10 \mathrm{mg} / \mathrm{ml}$; \#L1412; Sigma-Aldrich). The enzyme mixture was filtered through an 8- $\mu \mathrm{m}$ SCWP filter membrane (Millipore Corp., Billerica, MA, U.S.A.) followed by filtration through a $0.22-\mu \mathrm{m}$ MILLEX GP sterile filter membrane (Millipore Corp.). A Falcon tube with $20 \mathrm{ml}$ of filter-sterilized enzyme mixture and 0.5 $\mathrm{g}$ of mycelia was incubated at $28^{\circ} \mathrm{C}$ with shaking at $80 \mathrm{rpm}$ for 2 to $4 \mathrm{~h}$. The resultant protoplasts were filtered through two layers of sterile Miracloth (Calbiochem, EMD Biosciences, Inc., San Diego, CA, U.S.A.) to remove mycelial debris. After the protoplast solution was centrifuged at $1,500 \times g$ for $5 \mathrm{~min}$ at $4^{\circ} \mathrm{C}$, the pellet was rinsed once with $5 \mathrm{ml}$ of $\mathrm{KC}$ buffer and then resuspended gently with $1 \mathrm{ml}$ of $\mathrm{KC}$ buffer. The yield of protoplasts was determined with a hemacytometer. To regenerate protoplasts, $100 \mu \mathrm{l}$ of the protoplast suspension $\left(1 \times 10^{3}\right)$ was spread gently on $25 \mathrm{ml}$ of SH medium (0.6 M sucrose, 5

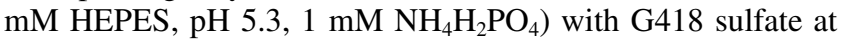
$75 \mu \mathrm{g} / \mathrm{ml}$. Two of the MfCUT1-GUS protoplast purified strains, designated P1 and P2, were selected for further analysis.

\section{Southern hybridization analysis.}

Genomic DNA $(1 \mu \mathrm{g})$ from M. fructicola was digested with restriction enzymes overnight. The concentration of digested DNA was quantified by fluorometry with Hoechst 33258. Digested DNA (500 ng) was separated on a $0.7 \%$ agarose gel and transferred overnight to a Hybond-N+ membrane (Amersham Biosciences, GE Healthcare, Waukesha, WI, U.S.A.). The AlkPHOs direct labeling kit (Amersham Biosciences) was used for probe preparation and hybridization. The two probes used in this research were approximately 650 and $500 \mathrm{bp}$ for probes 1 and 2, respectively. They were PCR amplified by Taq polymerase from pMfCUT1-GUS and gel purified after electrophoresis. The probe labeling with alkaline phosphatase and DNA hybridizations were performed according to the manufacturer's instructions (Amersham Biosciences). Hybridizations were performed overnight at $55^{\circ} \mathrm{C}$ and the primary washes were performed at $65^{\circ} \mathrm{C}$. The blots were developed with CDPStar chemiluminescent substrate (\#C0712, Sigma-Aldrich) and the density of each band determined by Kodak ID Image Analysis Software (Eastman Kodak Co, Rochester, NY, U.S.A.).

\section{RNA extraction.}

Mycelia from cultures grown on cutinase-inducing medium (Bostock et al. 1999) were lyophilized, and the dried mycelia (approximately $20 \mathrm{mg}$ ) were ground into a fine powder in liquid nitrogen. Total RNA was extracted by mixing the mycelial powder with $0.75 \mathrm{ml}$ of lysis buffer $(0.6 \mathrm{M} \mathrm{NaCl}, 10 \mathrm{mM}$ EDTA, $100 \mathrm{mM}$ Tris-HCl [pH 8.0], and 4\% SDS) and $0.75 \mathrm{ml}$ of phenol (Sokolovsky et al. 1990). After centrifugation of the mixture at $10,000 \mathrm{rpm}$ for $10 \mathrm{~min}$ at room temperature, the aqueous phase was then extracted with phenol one more time and precipitated in $6 \mathrm{M} \mathrm{LiCl}$ at $4{ }^{\circ} \mathrm{C}$ overnight. The LiCl-precipitated pellets were dissolved in water and the total fungal RNA was precipitated with sodium acetate and ethanol at $-20^{\circ} \mathrm{C}$ for $2 \mathrm{~h}$. After washing with $70 \%$ ethanol, the RNA pellets were dissolved in diethylpyrocarbonate-treated water and used for RT-PCR or stored at $-70^{\circ} \mathrm{C}$.

The Qiagen RNeasy plant mini kit (Qiagen Co., Valencia, CA, U.S.A.) was used to isolate total RNA from almond and peach flower petals inoculated with $M$. fructicola. Total RNA was extracted from 30 flower petals for each sample. Total RNA $(5 \mu \mathrm{g})$ was used for the RT reaction to generate cDNA, according to the manufacturer's directions.

\section{Sq-RT-PCR.}

We established a protocol for detection of MfCUT1 expression in infected plant tissue by sq-RT-PCR. Total RNA from a 
cutinase-induced $M$. fructicola culture was used to establish the standard RT-PCR reaction. Total RNA was isolated from M. fructicola cultures as described above but under the following modified growth conditions. A 9-cm petri dish with $20 \mathrm{ml}$ of cV8 broth was inoculated with $5 \times 10^{5}$ conidia and incubated for 3 days at room temperature. The $\mathrm{cV} 8$ broth was removed from the culture by centrifugation at 7,000 rpm for 10 min, and the resulting mycelial pellets were then washed twice with $20 \mathrm{ml}$ of sterile water with centrifugation at 7,000 rpm for $10 \mathrm{~min}$ for each wash. The washed mycelia were transferred to a new plate with $15 \mathrm{ml}$ of cutinase-inducing medium (Bostock et al. 1999). Total RNA was extracted as described above from the culture after additional incubation for 3 days at room temperature.

A partial sequence of the $M$. fructicola $\beta$-tubulin (TUB2) gene (Ma et al. 2003) (GenBank accession number AY283680) was selected as a suitable housekeeping gene to serve as an internal control for the sq-RT-PCR. The primers used for MfCUT1 and TUB2 were designed to include at least one intron so that PCR products amplified from cDNA had different sizes from those derived from genomic DNA. Therefore, primers tubF and tubR were designed specifically to the TUB2 gene and yielded a PCR product with $100 \mathrm{bp}$ of difference from the product amplified from genomic DNA. The total RNA from $M$. fructicola cultures and infected flower petals $(5 \mu \mathrm{g}$; discussed below) was converted to cDNA by SuperScript III reverse transcriptase (Invitrogen, Carlsbad, CA, U.S.A.). The RT reaction to generate cDNA was performed as described in the manufacturer's instructions. In total, $2 \mu \mathrm{l}$ of RT reaction mixture was used in a $50-\mu \mathrm{l} P C R$ reaction with tubF/R or cutF2/R2 using Taq polymerase (Promega Corp.). All RT reactions were performed using the cutR2 and tubR primers and all PCR reactions were performed using cutF2/R2 and tubF/R in the same reaction tubes. The primers cutR2 and tubR were selected for the RT reaction for the sq-RT-PCR because these proved to have greater specificity and sensitivity for MfCUT1 or TUB2 than cutF2 and tubF, respectively. The PCR program used was as follows: an initial reaction at $94^{\circ} \mathrm{C}$ for $2 \mathrm{~min} ; 40$ cycles of $94^{\circ} \mathrm{C}$ for $30 \mathrm{~s}, 55^{\circ} \mathrm{C}$ for $40 \mathrm{~s}$, and $72^{\circ} \mathrm{C}$ for $1 \mathrm{~min}$; followed by an additional $10-\mathrm{min}$ extension at $72^{\circ} \mathrm{C}$. PCR reaction mixture $(5 \mu \mathrm{l})$ was collected after $15,20,25,30,35$, and 40 cycles and was visualized by electrophoresis using $1.2 \%$ agarose gels and staining with ethidium bromide. The density of each band was determined by Kodak ID Image Analysis Software and the ratio of the MfCUT1 relative to TUB2 band density calculated. Total RNA (20 pg) was the minimally detectable concentration in a dilution series for MfCUT1 and TUB2 expression after 40 cycles of PCR reaction. Only PCR products amplified within the exponential stage of the reaction were used for these determinations.

\section{RNA gel-blot analysis.}

For RNA blot analyses, each sample ( $20 \mu \mathrm{g}$ of RNA) was analyzed in a denaturing gel as described (Sambrook and Russell 2001). A 500-bp PCR product of the MfCUT1 ORF was used as a probe. The AlkPHOs Direct Labeling kit was used for probe preparation and hybridization. Hybridizations and the primary washes were performed at $55^{\circ} \mathrm{C}$. The blots were developed with CDP-Star chemiluminescent substrate and the density of each band determined by Kodak ID Image Analysis Software (Eastman Kodak Co.).

\section{Plant inoculations.}

Conidia were collected from V8 agar cultures with a surgical blade to minimize carryover of nutrients from the medium. Conidia were suspended in sterile water and the concentrations were adjusted to $1 \times 10^{5}$ or $5 \times 10^{4}$ spores $/ \mathrm{ml}$ with sterile wa- ter. Then, 5- $\mu$ l drops of the spore suspension were applied to onion epidermal strips floating on water and incubated at room temperature. Flowers of almond ( $P$. dulcis (Mill.) Webb), nectarine ( $P$. persica var. nectarina Maxim), peach $(P$. persica L.), and cherry $(P$. avium L.) were collected from the orchard and petals were detached and placed in a moist chamber. Spore suspensions $(5 \mu \mathrm{l})$ of the WT strain MUK1 and the MfCUT1GUS strain P1 or P2 were inoculated onto each half of the adaxial surface of a flower petal. Due to the small size of cherry petals, each petal was inoculated with a single strain with a 5- $\mu$ l drop containing 500 conidia. Brown rot symptoms were photographed with a digital camera and the lesion size was measured using Spot image analysis software (Spot RT Software version 3.5.1; Diagnostic Instruments, Inc., Sterling Heights, MI, U.S.A.). Flower petals also were extracted for total RNA and analyzed for cutinase gene expression by sqRT-PCR as described above.

For fruit inoculations, fruit were surface sterilized with $10 \%$ bleach for $30 \mathrm{~s}$, rinsed in water, and then allowed to dry overnight at room temperature. They were placed in plastic containers above a layer of water for humidification and either wound inoculated by applying a $10-\mu$ drop of conidia $(2.5 \times$ $10^{4}$ conidia/ml) directly to a fresh $2-\mathrm{mm}$-deep wound created with a sterile 18-gauge needle or inoculated in a similar fashion but without wounding. The containers were covered to maintain high humidity and incubated at room temperature $\left(25^{\circ} \mathrm{C}\right)$. Maximum lesion diameters surrounding the point of inoculation were measured at 48 and $72 \mathrm{hpi}$.

Experiments were conducted at least twice within each host species. In some cases, different cultivars were used, depending on the seasonal availability of suitable host tissue. The significance of treatments was determined by analysis of variance and means comparisons using a paired $t$ test, as implemented in PC-SAS (SAS Institute, Cary, NC, U.S.A.). Additional details are provided in the tables.

\section{Induction and detection of cutinase.}

Conidia from 7- to 10-day-old V8 agar cultures were collected with sterile water and passed through one layer of Miracloth to remove mycelia. Modified Czapek-Dox broth $(20 \mathrm{ml})$ containing $0.1 \%$ glucose $(\mathrm{mCZ})$ was used as a starter medium. $\mathrm{mCZ}$ was inoculated with a conidial suspension of $M$. fructicola to a final concentration of $10^{4}$ spores $/ \mathrm{ml}$ (Bostock et al. 1999). After static incubation at $23^{\circ} \mathrm{C}$ for 3 days, the culture medium was removed and the mycelia washed twice with sterile water. Cutinase-inducing medium, $\mathrm{mCZ}$ without glucose and yeast extract but containing $0.1 \%$ (wt/vol) 16-hydroxyhexadecanoic acid (16-HHA) as a carbon source, was added to the washed mycelia. After incubation for $24 \mathrm{~h}$, mycelia were collected by filtration and stored at $-80^{\circ} \mathrm{C}$ until RNA extraction for sq-RT-PCR. Culture filtrates were stored at $-20^{\circ} \mathrm{C}$ for determination of cutinase enzyme activity by PNB hydrolysis as described previously (Lee and Bostock 2007b).

\section{$\mathrm{H}_{2} \mathrm{O}_{2}$ treatment.}

The effect of $\mathrm{H}_{2} \mathrm{O}_{2}$ on cutinase expression was tested by a medium shift assay similar to that described above. Briefly, $M$. fructicola was cultured in $\mathrm{mCZ}$ starter medium for 3 days and then shifted to cutinase-inducing medium amended with various concentrations of $\mathrm{H}_{2} \mathrm{O}_{2}$. The mycelia were harvested by filtration after 12 and $24 \mathrm{~h}$ in the cutinase-inducing medium and stored at $-80^{\circ} \mathrm{C}$ until extraction for RNA. The experiment was performed twice.

\section{GUS detection.}

GUS activity was detected as described by van Kan and colleagues (1997). 


\section{ACKNOWLEDGMENTS}

We thank K.-R. Chung, S. Daubert, L. Epstein, and T. Gordon for their critical review of M.-H. Lee's dissertation and the work presented in this study; S. Marek, C. Kado, and J. Rollins for their helpful discussions; and D. Johnson, S. Krishnan, and B. Harbert for their technical assistance. Research was supported in part by grants from the California Cling Peach Board and the US-Israel BARD program to R. M. Bostock and by grants from the National Science Council of Taiwan to M.-H. Lee.

\section{LITERATURE CITED}

Alarco, A.-M., Balan, I., Talibi, D., Mainville, N., and Raymond, M. 1997. AP1-mediated multidrug resistance in Saccharomyces cerevisiae requires FLR1 encoding a transporter of the major facilitator superfamily. J. Biol. Chem. 272:19304-19313.

Andreotti, C., Ravaglia, D., Ragaini, A., and Costa, G. 2008. Phenolic compounds in peach (Prunus persica) cultivars at harvest and during fruit maturation. Ann. Appl. Biol. 153:11-23.

Arrigo, A.-P. 1999. Gene expression and the thiol redox state. Free Radical Biol. Med. 27:936-944.

Baker, C. J., and Bateman, D. F. 1978. Cutin degradation by plant pathogenic fungi. Phytopathology 68:1577-1584.

Bonnen, A. M., and Hammerschmidt, R. 1989. Role of cutinolytic enzymes in infection of cucumber by Colletotrichum lagenarium. Physiol. Mol. Plant Pathol. 35:475-482.

Bostock, R. M., Wilcox, S. M., Wang, G., and Adaskaveg, J. E. 1999. Suppression of Monilinia fructicola cutinase production by peach fruit surface phenolic acids. Physiol. Mol. Plant Pathol. 54:37-50.

Bundock, P., and Hooykaas, P. J. J. 1996. Integration of Agrobacterium tumefaciens T-DNA in the Saccharomyces cerevisiae genome by illegitimate recombination. Proc. Natl. Acad. Sci. U.S.A. 93:15272-15275.

Choquer, M., Boccara, M., and Vidal-Cros, A. 2003. A semi-quantitative RT-PCR method to readily compare expression levels within Botrytis cinerea multigenic families in vitro and in planta. Curr. Genet. 43:303309.

Crowhurst, R. N., Binnie, S. J., Bowen, J. K., Hawthorne, B. T., Plummer, K. M., Rees-George, J., Rikkerink, E. H. A., and Templeton, M. D. 1997. Effect of disruption of a cutinase gene (cutA) on virulence and tissue specificity of Fusarium solani f. sp. cucurbitae race 2 toward $\mathrm{Cu}$ curbita maxima and C. moschata. Mol. Plant-Microbe Interact. 10:355368.

Cruickshank, R. H., and Wade, G. C. 1992. Production of appressoria by Monilinia fructicola. Mycol. Res. 96:425-428.

Cubero, B., and Scazzocchio, C. 1994. Two different, adjacent and divergent zinc finger binding sites are necessary for CREA-mediated carbon catabolite repression in the proline gene cluster of Aspergillus nidulans. EMBO (Eur. Mol. Biol. Organ.) J. 13:407-415.

da Silva, T. A., and Paccola-Meirelles, L. D. 2001. Reduction of the number of nuclei per cell of Helminthosporium euphorbiae by protoplast isolation. Mycoscience 42:313-320.

Davies, K. A., De Lorono, I., Foster, S. J., Li, D., Johnstone, K., and Ashby, A. M. 2000. Evidence for a role of cutinase in pathogenicity of Pyrenopeziza brassicae on brassicas. Physiol. Mol. Plant Pathol. 57:6375.

Dean, R. A., Talbot, N. J., Ebbole, D. J., Farman, M. L., Mitchell, T. K., Orbach, M. J., Thon, M., Kulkarni, R., Xu, J. R., Pan, H., Read, N. D., Lee, Y. H., Carbone, I., Brown, D., Oh, Y. Y., Donofrio, N., Jeong, J. S., Soanes, D. M., Djonovic, S., Kolomiets, E., Rehmeyer, C., Li, W., Harding, M., Kim, S., Lebrun, M. H., Bohnert, H., Coughlan, S., Butler, J., Calvo, S., Ma, L. J., Nicol, R., Purcell, S., Nusbaum, C., Galagan, J. E., and Birren, B. W. 2005. The genome sequence of the rice blast fungus Magnaporthe grisea. Nature 434:980-986.

Dickman, M. B., and Patil, S. S. 1986. Cutinase deficient mutants of Colletotrichum gloeosporioides are nonpathogenic to papaya fruit. Physiol. Mol. Plant Pathol. 28:235-242.

Dickman, M. B., Patil, S. S., and Kolattukudy, P. E. 1983. Effects of organophosphorous pesticides on cutinase activity and infection of papayas by Colletotrichum gloeosporioides. Phytopathology 73:1209-1214.

Ettinger, W. F., Thukral, S. K., and Kolattukudy, P. E. 1987. Structure of cutinase gene complementary DNA and the derived amino acid sequence from phytopathogenic fungi. Biochemistry 26:7883-7892.

Feliciano, A., Feliciano, A. J., and Ogawa, J. M. 1987. Monilinia fructicola resistance in the peach cultivar Bolinha. Phytopathology 77:776780

Gleave, A. P. 1992. A versatile binary vector system with a T-DNA organisational structure conducive to efficient integration of cloned DNA into the plant genome. Plant Mol. Biol. 20:1203-1207.

Govrin, E. M., and Levine, A. 2000. The hypersensitive response facili- tates plant infection by the necrotrophic pathogen Botrytis cinerea. Curr. Biol. 10:751-757.

Gradziel, T. M., Bostock, R. M., and Adaskaveg, J. E. 1998. Resistance to brown rot disease in peach is determined by multiple structural and biochemical components. Acta Hortic. 622:347-352.

Hellens, R., Mullineaux, P., and Klee, H. 2000. A guide to Agrobacterium binary Ti vectors. Trends Plant Sci. 5:446-451.

Lee, M. H., and Bostock, R. M. 2006a. Agrobacterium T-DNA-mediated integration and gene replacement in the brown rot pathogen Monilinia fructicola. Curr. Genet. 49:309-322.

Lee, M. H., and Bostock, R. M. 2006b. Induction, regulation, and role in pathogenesis of appressoria in Monilinia fructicola. Phytopathology 96:1072-1080.

Lee, M. H., and Bostock, R. M. 2007. Fruit exocarp phenols in relation to quiescence and development of Monilinia fructicola infections in Prunus spp.: a role for cellular redox? Phytopathology 97:269-277.

Li, D., Sirakova, T., Rogers, L., Ettinger, W. F., and Kolattukudy, P. E. 2002. Regulation of constitutively expressed and induced cutinase genes by different zinc finger transcription factors in Fusarium solani f. sp. pisi (Nectria haematococca). J. Biol. Chem. 277:7905-7912.

Ma, Z., Yoshimura, M. A., and Michailides, T. J. 2003. Identification and characterization of benzimidazole resistance in Monilinia fructicola from stone fruit orchards in California. Appl. Environ. Microbiol. 69:7145-7152.

Ma, Z. H., Boehm, E. W. A., Luo, Y., and Michailides, T. J. 2001. Population structure of Botryosphaeria dothidea from pistachio and other hosts in California. Phytopathology 91:665-672.

Marzluf, G. A. 1997. Genetic regulation of nitrogen metabolism in the fungi. Microbiol. Mol. Biol. Rev. 61:17-32.

Ogawa, J. M., Zehr, E. I., Bird, G. W., Ritchie, D. F., Uriu, K., and Uyemoto, J. K. 1995. Compendium of Stone Fruit Diseases. American Phytopathological Society Press, St. Paul, MN, U.S.A.

Pascholati, S. F., Deising, H., Leite, B., Anderson, D., and Nicholson, R. L. 1993. Cutinase and non-specific esterase activities in the conidial mucilage of Colletotrichum graminicola. Physiol. Mol. Plant Pathol. 42:37-51.

Patel, R. M., van Kan, J. A. L., Bailey, A. M., and Foster, G. D. 2008. RNA-mediated gene silencing of superoxide dismutase (bcsod1) in Botrytis cinerea. Phytopathology 98:1334-1339.

Pratt, R. J., and Aramayo, R. 2002. Improving the efficiency of gene replacements in Neurospora crassa: a first step towards a large-scale functional genomics project. Fungal Genet. Biol. 37:56-71.

Premakumar, R., Sorger, G. J., and Gooden, D. 1980. Physiological characterization of a Neurospora crassa mutant with impaired regulation of nitrate reductase. J. Bacteriol. 144:542-551.

Primiano, T., Sutter, T. R., and Kensler, T. W. 1997. Redox regulation of genes that protect against carcinogens. Comp. Biochem. Physiol. B: Biochem. Mol. Biol. 118:487-497.

Rogers, L. M., Flaishman, M. A., and Kolattukudy, P. E. 1994. Cutinase gene disruption in Fusarium solani $\mathrm{f}$ sp. pisi decreases its virulence on pea. Plant Cell 6:935-945.

Sambrook, J., and Russell, D. W. 2001. Molecular Cloning, A Laboratory Manual. Cold Spring Harbor Laboratory Press, Cold Spring Harbor, NY, U.S.A.

Senter, S. D., and Callahan, A. 1990. Variability in the quantities of condensed tannins and other major phenols in peach fruit during maturation. J. Food Sci. 55:1585-1587.

Skamnioti, P., and Gurr, S. J. 2007. Magnaporthe grisea cutinase2 mediates appressorium differentiation and host penetration and is required for full virulence. Plant Cell 19:2674-2689.

Skamnioti, P., Furlong, R. F., and Gurr, S. J. 2008. Evolutionary history of the ancient cutinase family in five filamentous Ascomycetes reveals differential gene duplications and losses and in Magnaporthe grisea shows evidence of sub- and neo-functionalization. New Phytol. 180:711-721.

Sokolovsky, V., Kaldenhoff, R., Ricci, M., and Russo, V. E. A. 1990. Fast and reliable mini-prep RNA extraction from Neurospora crassa. Fungal Genet. Newsl. 37:41-43.

Soliday, C. L., Dickman, M. B., and Kolattukudy, P. E. 1989. Structure of the cutinase gene and detection of promoter activity in the 5' flanking region by fungal transformation. J. Bacteriol. 171:1942-1951.

Stahl, D. J., and Schafer, W. 1992. Cutinase is not required for fungal pathogenicity on pea. Plant Cell 4:621-629.

Strauss, J., Mach, R. L., Zeilinger S., Hartler, G., Stoffler, G., Wolschek, M., and Kubicek, C. P. 1995. Crel, the carbon catabolite repressor protein from Trichoderma reesei. FEBS (Fed. Eur. Biochem. Soc.) Lett. 376:103-107.

Sweigard, J. A., Chumley, F. G., and Valent, B. 1992. Disruption of a Magnaporthe grisea cutinase gene. Mol. Gen. Genet. 232:183-190.

Tanabe, K., Nishimura, S., and Kohmoto, K. 1988. Cutinase production by 
Alternaria alternata Japanese pear pathotype and its role in pathogenicity. Ann. Phytopathol. Soc. Jpn. 54:483-492.

Tomas-Barberan, F. A., Gil, M. I., Cremin, P., Waterhouse, A. L., HessPierce, B., and Kader, A. A. 2001. HPLC-DAD-ESIMS analysis of phenolic compounds in nectarines, peaches, and plums. J. Agric. Food Chem. 49:4748-4760.

Toone, W. M., Morgan, B. A., and Jones, N. 2001. Redox control of AP-1like factors in yeast and beyond. Oncogene 20:2336-2346.

Van Der Vlugt-Bergmans, C. J. B., Wagemakers, C. A. M., and Van Kan, J. A. L. 1997. Cloning and expression of the cutinase A gene of Botrytis cinerea. Mol. Plant-Microbe Interact. 10:21-29.

Van Gorsel, H. 1993. Physiological and biochemical changes associated with ripening and chilling injury of peach fruit. Ph.D. thesis, University of California, Davis, U.S.A.

van Kan, J. A. L., Van't Klooster, J. W., Wagemakers, C. A. M., Dees, D. C. T., and Van Der Vlugt-Bergmans, C. J. B. 1997. Cutinase A of Botrytis cinerea is expressed, but not essential, during penetration of Gerbera and tomato. Mol. Plant-Microbe Interact. 10:30-38.

Vautard, G., Cotton, P., and Fevre, M. 1999. The glucose repressor CRE1 from Sclerotinia sclerotiorum is functionally related to CREA from Aspergillus nidulans but not to the Mig proteins from Saccharomyces cerevisiae. FEBS (Fed. Eur. Biochem. Soc.) Lett. 453:54-58.

Waksman, G. 1988. Molecular cloning of genes expressed specifically during induction of cell wall degrading enzymes from Sclerotinia sclerotiorum and preliminary identification of a fungal $\beta$-galactosidase encoding gene by expression in Escherichia coli. Curr. Genet. 14:91-93.

Wang, G.-Y., Michailides, T. J., Hammock, B. D., Lee, Y.-M., and Bostock, R. M. 2000. Affinity purification and characterization of a cutinase from the fungal plant pathogen Monilinia fructicola (Wint.) Honey. Arch. Biochem. Biophys. 382:31-38.

Wang, G. Y., Michailides, T. J., Hammock, B. D., Lee, Y.-M., and Bostock, R. M. 2002. Molecular cloning, characterization, and expression of a redox-responsive cutinase from Monilinia fructicola (Wint.) Honey. Fungal Genet. Biol. 35:261-276.

AUTHOR-RECOMMENDED INTERNET RESOURCES

TESS, the transcription element search system: www.cbil.upenn.edu/tess Protocol Online, E. W. Boehm procedure:

www.protocol-online.org/prot/Detailed/1200.html 